\title{
Structure-based Discovery of a Series of NSD2-PWWP1 Inhibitor
}

Liwei Zhou, ${ }^{1, \#}$ Hong Yang, ${ }^{2, \#}$ Ke Liu, ${ }^{3, \#}$ Yuting Huang, ${ }^{2}$ Danyan Cao, ${ }^{1}$ Yanlian Li, ${ }^{1}$ Yaoliang Sun, ${ }^{4}$ Aisong Yu, ${ }^{2}$ Zhiyan Du, ${ }^{1}$ Feng Yu, ${ }^{3}$ Ying Zhang, ${ }^{2}$ Bingyang Wang, ${ }^{4}$ Meiyu Geng, ${ }^{2,5}$ Jian Li, ${ }^{6}$ Tongchao Liu, ${ }^{1, *}$ Shilin $\mathrm{Xu},{ }^{4,}$ Bing Xiong, ${ }^{1,}{ }^{*}$ Xun Huang ${ }^{2,5, *}$

${ }^{1}$ Department of Medicinal Chemistry, Shanghai Institute of Materia Medica, Chinese Academy of Sciences, 555 Zuchongzhi Road, Shanghai 201203, P. R. China

${ }^{2}$ Division of Antitumor Pharmacology, State Key Laboratory of Drug Research, Shanghai Institute of Materia Medica, Chinese Academy of Sciences, 555 Zuchongzhi Road, Shanghai 201203, P. R. China

${ }^{3}$ Shanghai Synchrotron Radiation Facility, Shanghai Advanced Research Institute, Chinese Academy of Sciences, 239 Zhangheng Road, Shanghai 201210, China

Drug Discovery \& Development Center, State Key Laboratory of Drug Research, Shanghai Institute of Materia Medica, Chinese Academy of Sciences, \#555 Zu Chong Zhi Road, Shanghai, 201203, China

${ }^{5}$ Hangzhou Institute for Advanced Study, UCAS, Hangzhou 310024, P. R. China;

${ }^{6}$ College of Pharmaceutical Sciences, Gannan Medical University, Ganzhou 341000,

China

${ }^{\#}$ These authors contributed equally

*Corresponding authors. Tel: +8621 50806600 ext. 5412 fax: +86 2150807088 . Email:

(T. L.) tongchao liu@simm.ac.cn; (B. X.) bxiong@simm.ac.cn; (S.X.) slxu@simm.ac.cn; (X.H.) xhuang@simm.ac.cn 


\section{Abstract}

Overexpression, point mutations or translocations of protein lysine methyltransferase NSD2 was occurred in many types of cancer cells. Therefore, it was recognized as oncoprotein and considered as a promising anticancer drug target. NSD2 consists of a SET catalytic domain and two PWWP domains binding to methylated histone proteins. Here, we reported our efforts to develop a series of NSD2 PWWP1 inhibitors, and further structure-based optimization resulted a potent inhibitor 38, which has the high selectivity towards NSD2 PWWP1 domain. The detailed biological evaluation revealed that compound $\mathbf{3 8}$ can bind to NSD2-PWWP1 and then affect the expression of genes regulated by NSD2. We believe that the current discovery will provide a useful chemical probe to the future research in understanding the specific regulation mode of NSD2 by PWWP1 recognition.

KEYWORDS: Epigenetics; NSD2; PWWP domain; Inhibitor; Structure-based drug discovery

\section{INTRODUCTION}

The nuclear receptor-binding SET domain (NSD) family of protein lysine methyltransferases consists of three members: NSD1, NSD2 and NSD3, and which predominantly catalyzes the mono- and di-methylation of histone 3 lysine $36(\mathrm{H} 3 \mathrm{~K} 36) .{ }^{1}$ High expression, point mutations or translocations of NSD family frequently occurred in multiple types of human cancers. NSD2, also known as MMSET (multiple myeloma 
SET domain) or WHSC1 (Wolf-Hirschhorn syndrome candidate 1) is involved in several cellular processes, including DNA damage repair, epithelial-mesenchymal transformation (EMT) and cell cycle regulation, and was identified as an important driver in oncogenesis. ${ }^{2}$ Notably, NSD2 is closely related to accelerated disease progression and rapid relapse in $15-20 \%$ of multiple myeloma (MM) harboring the $\mathrm{t}(4 ; 14)$ chromosomal translocation with increased levels of H3K36me $2,{ }^{3}$ and among the most frequently mutated genes in pediatric cancer genomes, E1099K mutant of NSD2 is hyperactivated in acute lymphoblastic leukemia. ${ }^{4}$ Recent studies have revealed that overexpression of NSD2 occurred in several solid tumors including bladder, prostate, glioblastoma and gastrointestinal..$^{5,6}$

NSD2 is a multi-domain protein, consists of the SET domain performing the catalytic methylation function and two PWWP (proline-tryptophan-tryptophan-proline) domains. The N-terminal PWWP domain (PWWP1) acts as the reader domain that preferentially binds to the nucleosomes containing H3K36me2while PWWP2 domain can bind to histone H3K36/79me3 and dsDNA. Though PWWP1 and PWWP2 are different in affinity to histone substrates, they have been reported to cooperate in maintaining appropriate nuclear localization. This process relies on the conserved aromatic cage consists of PWWP1 Y233, W236 and F266, which are orthogonally positioned and interact with the methylated side chain of H3K36 residue. The NSD2PWWP1:H3K36me2 interaction plays a critical role in stabilizing NSD2 at chromatin, and then facilitates epigenetic spreading and propagation of $\mathrm{H} 3 \mathrm{~K} 36 \mathrm{me} 2$ which is required for the recruitment of DNMT3A and maintenance of DNA methylation at 
intergenic regions for gene transcription. ${ }^{7}$ In carcinoma cells, H3K36me2 signal alteration underlies epithelial-to-mesenchymal transition and mesenchymal-toepithelial transition that is critical for metastatic. ${ }^{8}$

Since NSD2 is a promising target for targeted cancer therapy, several groups have reported their efforts in developing selective small-molecule inhibitors targeting the catalytic domain or the PWWP domains of NSD proteins (Figure 1). Huang et al. screened a fragment library of approximately 1600 fragment-like compounds against SET domain of NSD1 with 2D-NMR experiments and found 6-chloro-1,3benzothiazol-2-amine that binds to the SET domain. ${ }^{9}$ Further structure-based optimization was conducted and resulted to a covalent inhibitor BT5 (1) with moderate selectivity over NSD2 and NSD3. Bottcher et al. from Boehringer Ingelheim company adopted the fragment-based strategy to identify hits to the PWWP1 domain of NSD3. ${ }^{10}$ BI-9321(2) was discovered as a potent and selective inhibitor of NSD3-PWWP1 domain, with $\mathrm{IC}_{50}$ value of $0.2 \mu \mathrm{M}$ in the TR-FRET assay. Coussens et al. utilized the high-throughput screening to identify five small-molecules as inhibitors of the catalytic SET domain and compound 3 exhibited apparent activity in cells. ${ }^{11}$ Freitas et al. reported the first inhibitor (4) of NSD2-PWWP1 domain with $\mathrm{K}_{d}$ value about $3.4 \mu \mathrm{M}$ in an SPR assay, which could abrogate histone H3K36me2 binding to the PWWP1 domain in cells with an $\mathrm{IC}_{50}$ of $17.3 \mu \mathrm{M} .^{12}$

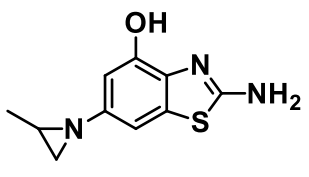

1. BT5 NSD1-SET

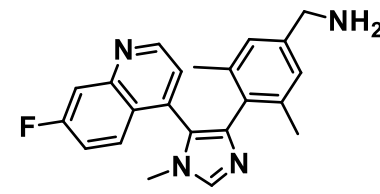

2. $\mathrm{BI}-9321$ NSD3-PWWP1<smiles>O=C1C(Cl)=C(NCCN2CCOCC2)C(=O)c2ncccc21</smiles>

3. DA3003-1 NSD2-SET

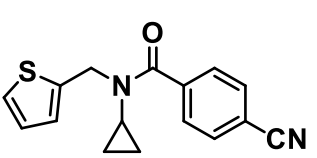

4. MR837 NSD2-PWWP1 
Figure 1. Representative small-molecule inhibitors of NSD1-3 proteins.

Since there is only one chemotype of NSD2 PWWP1 inhibitors that merely showed moderate binding activity, therefore, more potent NSD2 PWWP1 inhibitors need to be developed to further assess the pharmacological potential of NSD2. Herein, we reported our effort to conduct a structure-based optimization of NSD2 PWWP1 ligands, leading to a selective NSD2-PWWP1 inhibitor $\mathbf{3 8}$ with significantly improved potency. Compound 38 can clearly bind to NSD2-PWWP1 and further affect the expression of genes regulated by NSD2. We believe that the discovery and related biological evaluation will contribute to the further research of the specific regulation mode of NSD2 by PWWP1 recognition, and furthermore, our discovery also provided a certain material basis for the functional study of NSD2.

\section{RESULTS AND DISCUSSION}

\section{Rational Design of Selective NSD2-PWWP1 Inhibitors.}

At the initial stage of this project, we analyzed the binding model of reported small-molecule compounds to understand the binding basis between inhibitors and proteins, which enabled us to rationally design a new class of NSD2 inhibitors. Currently, the crystal structure of NSD2 PWWP1 domain bound with MR837 was reported (PDB ID: 6UE6) ${ }^{12}$, which revealed two important binding features: 1) Ncyclopropyl amide of MR837 occupied the aromatic cage sub-pocket forming by three conservative aromatic residues, Tyr233, Trp236 and Phe266; 2) an essential hydrogen bonding interaction between Ala270 residue and the $\mathrm{N}$ atom of benzonitrile. As 
mentioned above, BI-9321, the first selective and potent PWWP inhibitor in NSD family was reported by Bottcher et al. and demonstrated in the cocrystal structure (PDB code: $6 \mathrm{G} 2 \mathrm{O})^{10}$, binds to NSD3-PWWP1 domain by the following patterns: the aromatic cage was occupied by $\mathrm{N}$-methylimidazole ring; the $\mathrm{N}$ atom in the quinoline ring interacted with Ser314 through hydrogen bonding; and the $\mathrm{NH}_{2}$ of benzylamine extending out the binding pocket and forming a strong electrostatic interaction with nearby negative charged residue Glu318.

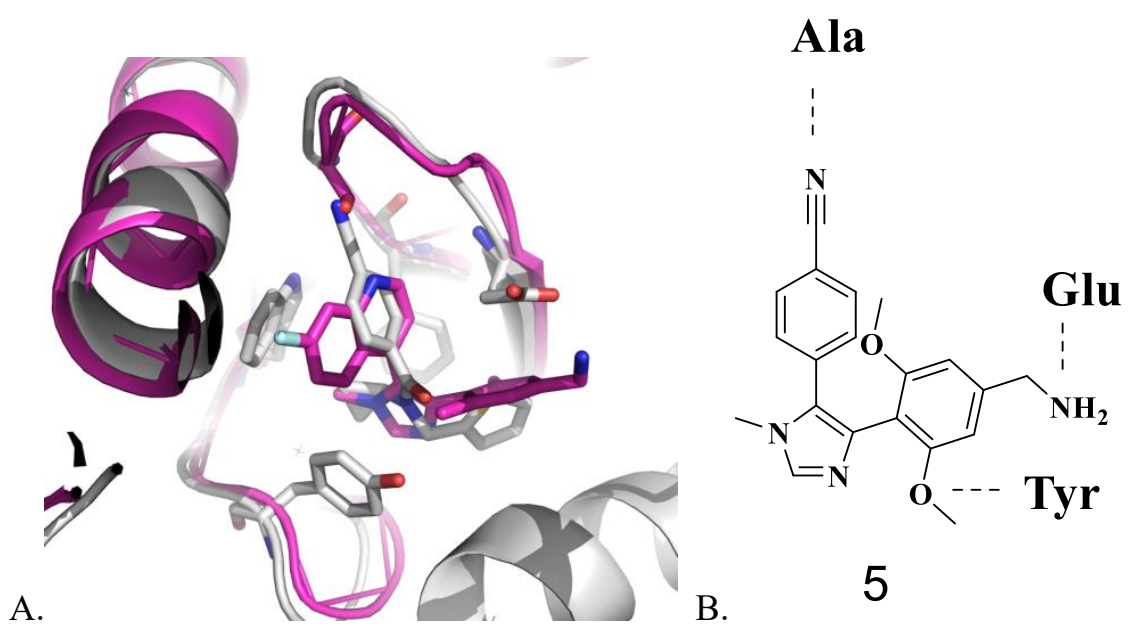

Figure 2. Design of NSD2-PWWP1 inhibitor based on the superimposition of crystal structure of PWWP inhibitors of NSD2-PWWP1 (MR837, PDB code 6UE6) and NSD3-PWWP1 (BI-9321, PDB code 6G2O).

By superposition of these two cocrystal structures (Figure 2A), it could be seen that, comparing the binding site of NSD3 PWWP1 domain with the NSD2 PWWP1 domain, the most striking difference is at the vicinity of benzonitrile group of MR837. In the NSD2 PWWP1 domain, there are Gly268, Asp269 and Ala270 residues forming hydrogen bonds with benzonitrile structure, while in NSD3 PWWP1 domain, at the 
same position, there are Ser314, Asn315 and Gln316 surrounding the quinolone ring of BI-9321. It should be noted that the side chain of Ser314 forming a hydrogen bond with the nitrogen atom of quinolone, which would impede the benzonitrile group binding. Therefore, we rationally designed the new chemotype of NSD2 PWWP1 inhibitors by incorporating the benzonitrile into the BI-9321 to replace the quinoline ring, which was thought that could achieve the binding selectivity of NSD2 over the NSD3 protein. Besides, we also noticed that the methyl group on the benzene ring of BI-9321 was at the similar position of the $\mathrm{O}$ atom of the amide group of MR837, and the distance between the methyl $\mathrm{C}$ atom on the benzene ring of BI-9321 and Tyr233 was $3.6 \AA$. We hypothesized that if the methyl on the benzene ring was replaced with methoxy group, the $\mathrm{O}$ atom of methoxyl group may be able to form a hydrogen bond with Tyr233. Taking together, we designed and synthesized compound $\mathbf{5}$ in Figure 2B for the biological test to verify the design strategy.

\section{Structure-Activity Relationship (SAR) Exploration and Optimization of Ligands.}

As shown in Table 1, compound $\mathbf{5}$ with two methoxy groups displayed a good binding affinity to NSD2 PWWP1 domain, with an $\mathrm{IC}_{50}$ value of $4.44 \mu \mathrm{M}$, which is much better than MR837 (4). This encouraged us to synthesize analogs 6-12. According to the binding assay, removal of one or two methoxy groups led to compounds $\mathbf{6}$ and $\mathbf{7}$ showing slightly reduced potency with $\mathrm{IC}_{50}$ values of $11.97 \mu \mathrm{M}$ and $13.95 \mu \mathrm{M}$, respectively. When mono-halogen groups such as chlorine and fluorine were introduced (compound $\mathbf{8}$ and $\mathbf{9}$ ), they also slightly reduced potency if comparison with compound 5. However, single trifluoromethyl-substituent and methyl-substituent compounds (10 
and 11) showed equal potency to compound 5. When another methyl group was introduced to yield compound $\mathbf{1 2}$, the potency was significantly improved to an $\mathrm{IC}_{50}$ value of $0.57 \mu \mathrm{M}$, about 8 -fold more potent than of compound 5. This encouraged us to further explore the effect of other parts of this chemotype inhibitors on NSD2 PWWP1 binding.

Table 1. NSD2 Inhibition of Compounds 5 - 12 Combining $\mathbf{R}^{1}$ - and $\mathbf{R}^{2}$ - Substituents ${ }^{a}$

\begin{tabular}{|c|c|c|c|}
\hline compound & $\mathrm{R}^{1}$ & $\mathrm{R}^{2}$ & NSD2 $\left(\mathrm{IC}_{50}, \mu \mathrm{M}\right)$ \\
\hline 5 & $\mathrm{OCH}_{3}$ & $\mathrm{OCH}_{3}$ & $4.44 \pm 3.30$ \\
\hline 6 & $\mathrm{OCH}_{3}$ & $\mathrm{H}$ & $11.97 \pm 3.64$ \\
\hline 7 & $\mathrm{H}$ & $\mathrm{H}$ & $13.95 \pm 6.73$ \\
\hline 8 & $\mathrm{Cl}$ & $\mathrm{H}$ & $6.11 \pm 3.38$ \\
\hline 9 & $\mathrm{~F}$ & $\mathrm{H}$ & $11.19 \pm 2.80$ \\
\hline 10 & $\mathrm{CF}_{3}$ & $\mathrm{H}$ & $6.01 \pm 2.02$ \\
\hline 11 & $\mathrm{CH}_{3}$ & $\mathrm{H}$ & $4.68 \pm 2.12$ \\
\hline 12 & $\mathrm{CH}_{3}$ & $\mathrm{CH}_{3}$ & $0.57 \pm 0.12$ \\
\hline MR837 & - & - & $24.67 \pm 1.86$ \\
\hline
\end{tabular}

${ }^{a} \mathrm{IC}_{50}$ values are shown as the mean $\pm \mathrm{SD}$ from at least two separate determinations. 


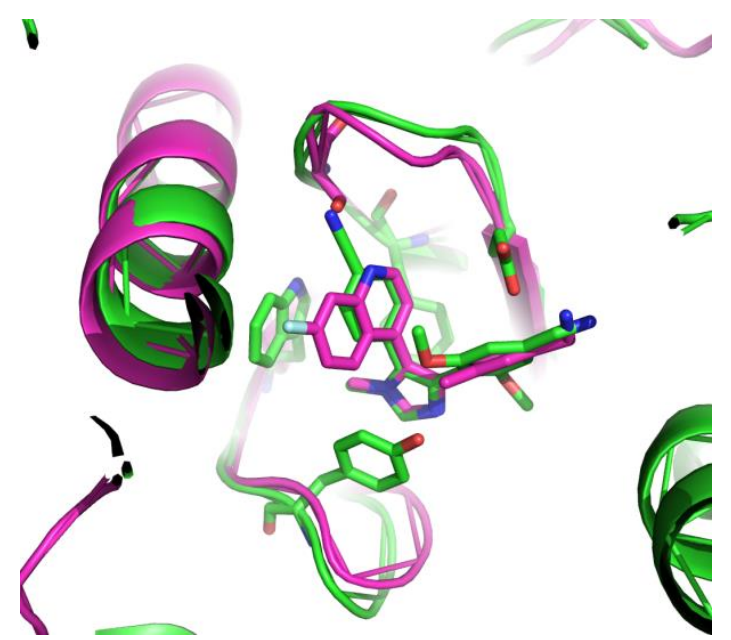

Figure 3. Superimposition of the crystal structure of NSD2 PWWP1 domain with compound 5 (colored green, PDB ID:7VLN) and the crystal structure of NSD3 PWWP1 bound with BI-9321 (colored purple, PDB ID:6G2O).

To verify the design, we performed the crystallization experiment and solved the cocrystal structure of NSD2 PWWP1 domain with compound 5. As illustrated in Figure 3, compound $\mathbf{5}$ bound to the NSD2 in a mode very similar to BI-9321 bound to the NSD3: the N-methylimidazole situated into the aromatic cage and the benzylamine group interacted with the nearby Glu277; while the benzonitrile motif represents as an essential pharmacophore for PWWP1 of NSD2, which, as predicted, interacts with residues Asp269 and Ala270. Clearly, the nitrile group would be collided with the serine residue in NSD3.

Based on this solved structure, we next conducted a series of structural modifications to get compounds $\mathbf{1 3}-\mathbf{2 0}$ to further explore the interactions with this benzonitrile binding subpocket. As shown in Table 2, replacement of the benzonitrile core of compound $\mathbf{1 2}$ with a naphthonitrile moiety led to compound $\mathbf{1 3}$ showing 
analogous potency with an $\mathrm{IC}_{50}$ value of $0.52 \mu \mathrm{M}$. Further replacement of the naphthalene moiety with a quinoline moiety generated compound $\mathbf{1 4}$ showing an $\mathrm{IC}_{50}$ value of $1.58 \mu \mathrm{M}, 3$-fold less potent than compound 13. Introducing an amino- or methylamino-substituent in the ortho-position of cyano group of compound $\mathbf{1 2}$ reduced the potency (compound $\mathbf{1 5}$ and 16). Introduction of other small substituents afforded compounds 17 - 20. Unfortunately, all these compounds exhibited less activity against NSD2. These results indicate that limited structural variations are tolerated in this region and the naphthonitrile framework remains to be advantageous to interact with NSD2. Because compound $\mathbf{1 3}$ is slightly more potent, and protein thermal shift assay (TSA) experiment further confirmed that compound $\mathbf{1 3}$ can selectively bind to NSD2 PWWP1 protein more tightly than compound 12 (Figure S1), we selected compound 13 for further structural optimization with the central naphthonitrile core intact.

Table 2. NSD2 Inhibition of Compounds Bearing Different Aromatic Cyano-Fragments ${ }^{a}$

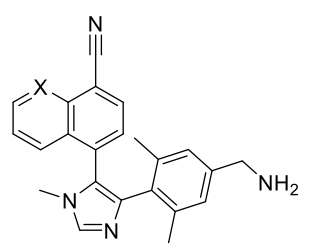

13: $\mathrm{X}=\mathrm{C}, 14: \mathrm{X}=\mathrm{N}$

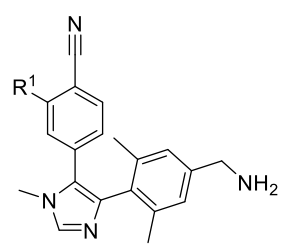

15 - 20

\begin{tabular}{ccc}
\hline compound & $\mathrm{R}^{1}$ & NSD2 $\left(\mathrm{IC}_{50}, \mu \mathrm{M}\right)$ \\
\hline $\mathbf{1 3}$ & - & $0.52 \pm 0.20$ \\
$\mathbf{1 4}$ & - & $1.58 \pm 0.85$ \\
$\mathbf{1 5}$ & $\mathrm{NH}_{2}$ & $8.78 \pm 2.18$ \\
$\mathbf{1 6}$ & $\mathrm{NHCH}_{3}$ & $>20$ \\
$\mathbf{1 7}$ & $\mathrm{F}$ & $2.91 \pm 0.13$ \\
\hline
\end{tabular}




\begin{tabular}{lcc}
\hline $\mathbf{1 8}$ & $\mathrm{Cl}$ & $5.03 \pm 2.60$ \\
$\mathbf{1 9}$ & $\mathrm{OCH}_{3}$ & $10.93 \pm 7.33$ \\
$\mathbf{2 0}$ & $\mathrm{CF}_{3}$ & $15.41 \pm 1.82$ \\
\hline
\end{tabular}

${ }^{a} \mathrm{IC}_{50}$ values are shown as the mean $\pm \mathrm{SD}$ from at least two separate determinations.

From the cocrystal structure of NSD3 PWWP1 in complex with BI-9321, we can learn that the benzylamine group interacts with E318 residue by a hydrogen bond and this residue is conserved in the PWWP1 domain of NSD2. We synthesized and tested compounds bearing different hydrogen bond groups as the replacement of the benzylamine group. As shown in Table 3, almost all these compounds lost activity against NSD2 by showing $\mathrm{IC}_{50}$ values greater than $20 \mu \mathrm{M}$. Notably, compounds 24 and 27 showed much reduced potency with $\mathrm{IC}_{50}$ values of $13.81 \mu \mathrm{M}$ and $10.56 \mu \mathrm{M}$, respectively. These results indicated that benzylamine group was necessary for activity against NSD2 and minor modifications led to much reduced potency.

Table 3. NSD2 Inhibition of Compounds Bearing Different H-bond Donor Groups ${ }^{a}$

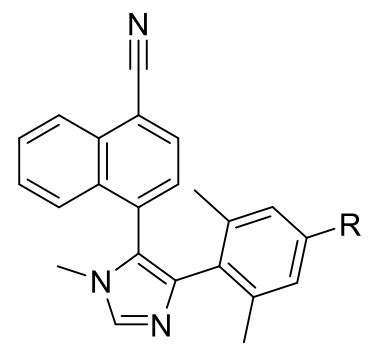

\begin{tabular}{ccc}
\hline compound & $\mathrm{R}$ & NSD2 $\left(\mathrm{IC}_{50}, \mu \mathrm{M}\right)$ \\
\hline 21 & $\mathrm{CN}$ & $>20$ \\
22 & $\mathrm{CHO}$ & $>20$ \\
\hline
\end{tabular}




\begin{tabular}{ccc}
\hline $\mathbf{2 3}$ & $\mathrm{COCH}_{2} \mathrm{CH}_{3}$ & $>20$ \\
$\mathbf{2 4}$ & $\mathrm{CH}_{2} \mathrm{OH}$ & $13.81 \pm 0.47$ \\
$\mathbf{2 5}$ & $\mathrm{CHOHCH}_{2} \mathrm{CH}_{3}$ & $>20$ \\
$\mathbf{2 6}$ & $\mathrm{NHBoc}^{27}$ & $>20$ \\
& & $10.56 \pm 3.31$ \\
\hline
\end{tabular}

${ }^{a} \mathrm{IC}_{50}$ values are shown as the mean \pm SD from at least two separate determinations.

During the exploration of SARs, we found that tert-butoxycarbonyl-protected compound 13, compound 28 still showed moderate potency with an $\mathrm{IC}_{50}$ value of 1.67 $\mu \mathrm{M}$. This indicated that there is certain space around this binding subsite to conduct structural modifications. Therefore, we further explored steric and hydrophilic tolerance by introducing bulky alkyl- or water-soluable substituents. As shown in Table 4, The $N$-ethyl substituted compound 29, $N$-cyclopropyl substituted compound $\mathbf{3 0}$ and $N$-tert-butyl substituted compound $\mathbf{3 1}$ displayed increased potency with $\mathrm{IC}_{50}$ values of $0.70 \mu \mathrm{M}, 0.43 \mu \mathrm{M}$ and $0.64 \mu \mathrm{M}$, respectively, which were equivalent to compound 13 . When the nitrogen was double substituted to afford compounds $\mathbf{3 2}-\mathbf{3 6}$, they showed decreased potency with $\mathrm{IC}_{50}$ values ranging from $1.49 \mu \mathrm{M}$ to $8.07 \mu \mathrm{M}$. However, removal of Boc protection led to significantly increased potency (compound $\mathbf{3 7}$ and 38), with an $\mathrm{IC}_{50}$ value of $1.89 \mu \mathrm{M}$ and $0.11 \mu \mathrm{M}$, respectively. Introduction of a hydroxyl group at the C3-position of compound 32 led to 4-fold increased potency (compound 39), while the dimethylamino group led to retained potency (compound 40) compared to corresponding compound 32. Replacement of the amino piperidine of compound $\mathbf{3 8}$ with an ethylenediamine yielded compound 41 showing 6-fold reduced potency. 
Notably, among these compounds, compound $\mathbf{3 8}$ showed the best potency against NSD2, 5-fold more potent than compound 13.

Table 4. NSD2 Inhibition of Compounds Bearing Variable Amino Substituents ${ }^{a}$

$\mathbf{3 2}$


${ }^{a} \mathrm{IC}_{50}$ values are shown as the mean $\pm \mathrm{SD}$ from at least two separate determinations.

\section{Biological Evaluation}

\section{Selectivity profile with Protein Thermal shift}

We carried out protein thermal shift assay to directly confirm the binding between NSD2-PWWP protein and compound 38. As shown in Fig 4, compared to DMSO control, the melting temperature (Tm values) of NSD2-PWWP1 protein was evidently increased due to the addition of $\mathbf{3 8}$ and the Change of melting temperature (Tm) in a dose-dependent manner at concentrations from $0.781 \mu \mathrm{M}$ to $200 \mathrm{mM}$. The results demonstrated that the ligands directly bind to NSD2-PWWP protein and could strengthen its stability in vitro. We further evaluated the target binding specificity of $\mathbf{3 8}$ using the thermal shift assay. Our results show that $\mathbf{3 8}$ exhibited remarkable selectivity against NSD2-PWWP1 protein over other PWWP domains protein (NSD3-PWWP1, DNMT3A-PWWP, ZCWPW1-PWWP).
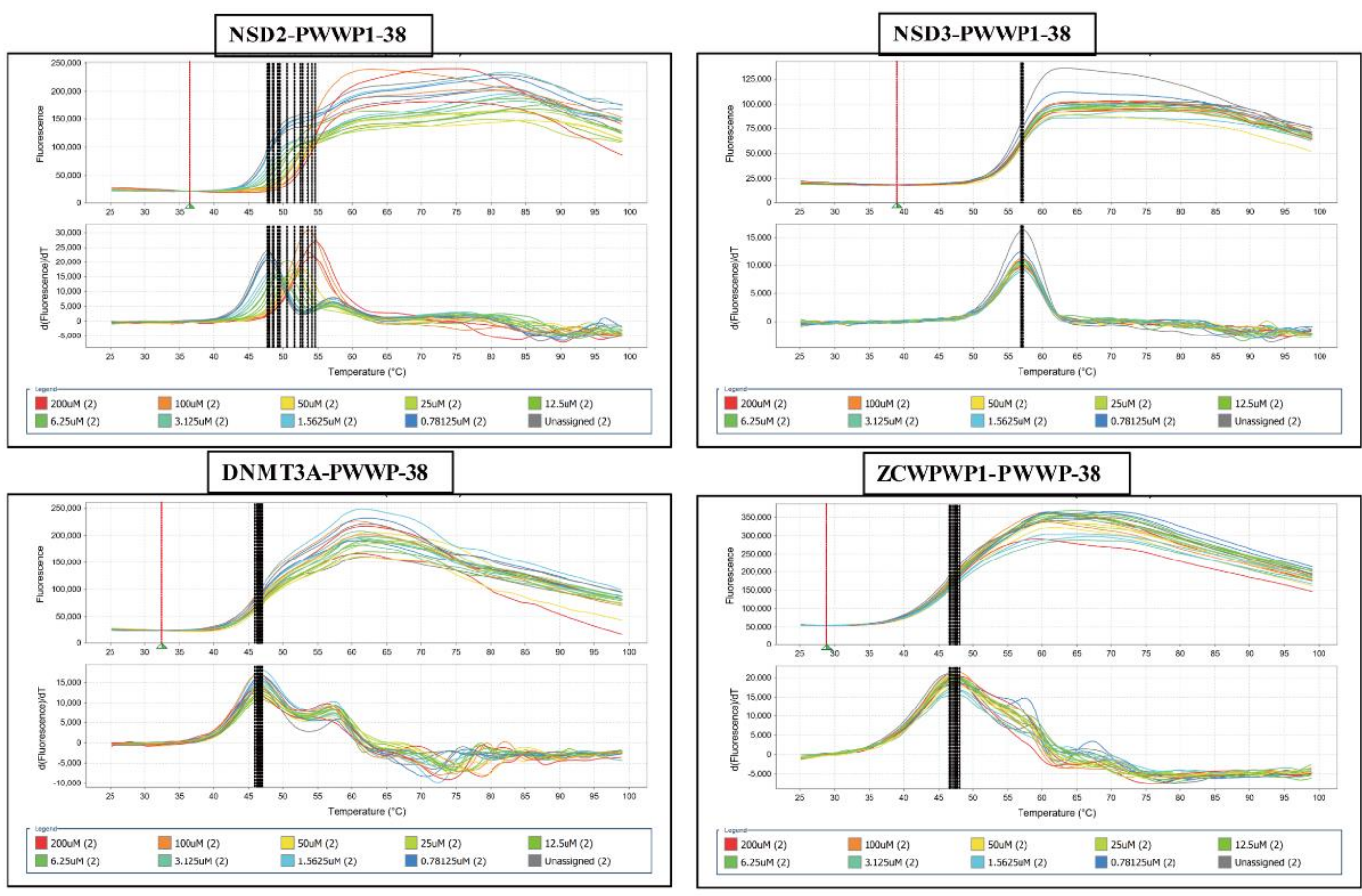

Figure 4. The melting curves of PWWP domains protein protein with $\mathbf{3 8}$. The thermal 
shift assay displayed that treatment with $\mathbf{3 8}$ increases the melting temperature. $\mathbf{3 8}$ exhibited remarkable selectivity against NSD2-PWWP1 protein over other PWWP domains protein (NSD3-PWWP1, DNMT3A-PWWP, ZCWPW1-PWWP).

\section{Target validation in molecular and cellular level}

We proved in the previous section that compound $\mathbf{3 8}$ could bind to PWWP domains. To further detect whether $\mathbf{3 8}$ can affect HK36me2, we adopted AlphaLisa which was designed for screening NSD2 enzymatic inhibitors. It was shown that $\mathbf{3 8}$ did not display inhibition effect on H3K36me2 in vitro(Figure 5A). Consistent with Alphalisa results, 38 caused little effect on general H3K36me2 in cellular level(Figure 5B). In conclusion, $\mathbf{3 8}$ had no impact on SET domain or enzyme activity catalytic function, which further validated that 38 could specifically binds to PWWP domain.

A

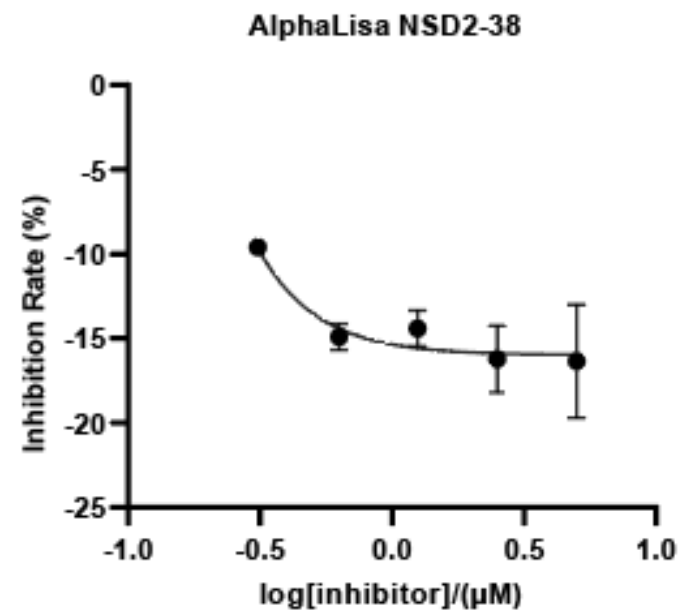

B

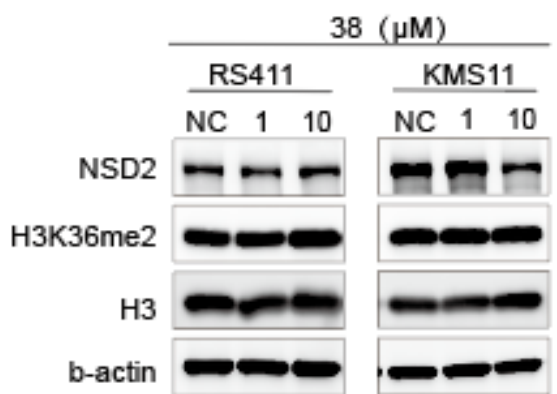

Figure 5. Target validation of $\mathbf{3 8}$ in molecular and cellular level. (A) The inhibition of 38 on the H3K36me2 level via Alphalisa screening. (B) RS4:11 and KMS11 cells were treated with 38 at gradient concentrations for 3 days, and the protein level of H3K36me 2 wasdetected by western blot. $\beta$-actin was used as a loading control. Data 
are reported as the mean $\pm \mathrm{SD}$.

\section{NSD2-positive correlated downstream genes validation}

We next determined whether 38 could affect NSD2 correlated downstream genes. The expression of several published representative genes [3] [4] (PAK1,RRAS2,TCFA,TEMEL2,HSPG2,NCAM1) were validated in two cancer cell lines by qRT-PCR analysis. Six pairs of qPCR primers of were designed. RT-PCR results showed that NSD2 target genes PAK1, RRAS2, TGFA, TEMEL2, NCAM1 remarkably decreased in compound $\mathbf{3 8}$ treatment group compared with control in MV4;11 and KMS11 cell lines, except for HSPG2. These results confirmed compound 38 could affect NSD2 correlated downstream genes changes (Figure 6). A previous study indicate that NSD2-PWWP1 mutation can slightly reduce H3K36me2 level. ${ }^{13}$ However, we found that interruption ofNSD2 and H3K36me2 can downregulate gene transcription without influence of H3K36me2 level. These results confirm a multiple function protein of NSD2 according to its structure.
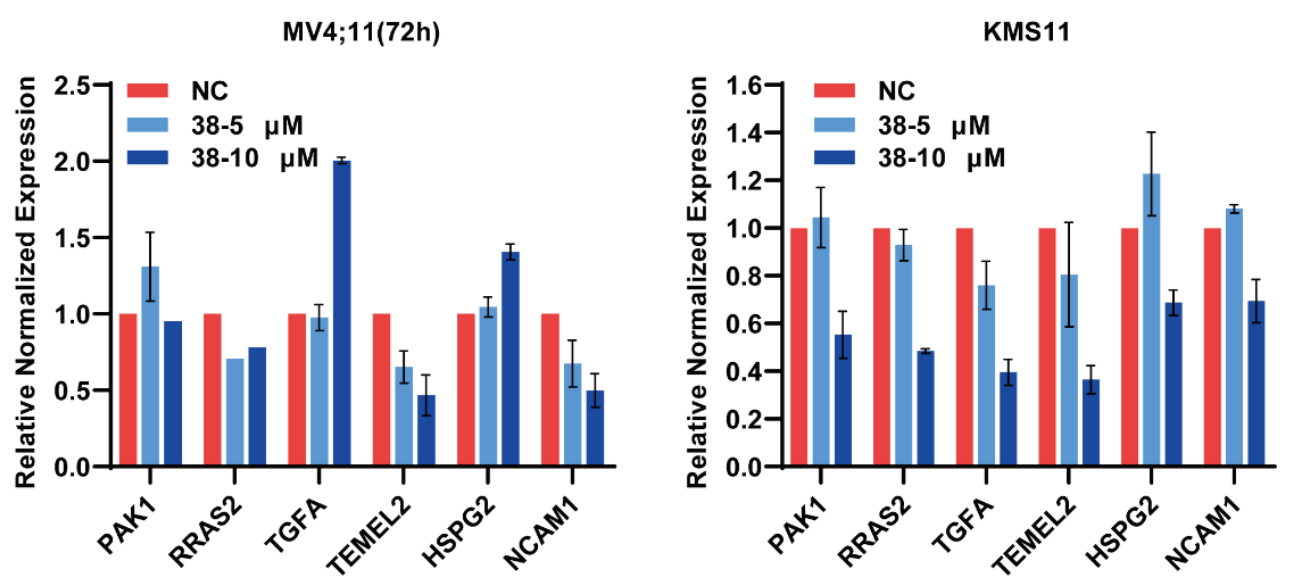

Figure 6. Downstream oncogenic transcriptional programs of compound 38. The effects of $\mathbf{3 8}$ on gene expressions in 2 cell lines. The cell lines were treated with vary concentrations of $\mathbf{3 8}$ for 3 days. Data are reported as the mean \pm SD.

\section{Cell-based activity}


We then assessed the potential antitumor activity of $\mathbf{3 8}$ in vitro, we evaluated its effects on cell proliferation in a panel of human cell lines. The results demonstrated that 38 inhibited cell proliferation in these cell lines, including the cell line RS4:11( $\left.\mathrm{IC}_{50}=6.30 \mu \mathrm{M}\right) \quad, \quad \mathrm{MV} 4 ; 11\left(\mathrm{IC}_{50}=2.23 \mu \mathrm{M}\right), \quad \mathrm{KMS}_{11}\left(\mathrm{IC}_{50}=8.43 \mu \mathrm{M}\right), \quad$ and MM1S( $\left(\mathrm{IC}_{50}=10.95 \mu \mathrm{M}\right) . \quad$ (Fig. 7). Our previous study reported a NSD2-SET domain inhibitor 9c which showed great inhibitory effect in NSD2 mutant cells KMS11 and RS4:11( $\mathrm{IC}_{50}$ were $0.52 \mu \mathrm{M}, 1.88 \mu \mathrm{M}$ respectively).However, NSD2 WT cell MV4;11 showed little response to $9 \mathrm{c} .{ }^{14}$ In this study, NSD2-PWWP1 inhibitor $\mathbf{3 8}$ showed inhibitory effect in both NSD2 mutant and wild type cells. Therefore, we speculated that NSD2-PWWP1 inhibitor inhibited cell proliferation independent of NSD2 genotype, which was different from NSD2-SET inhibitor.

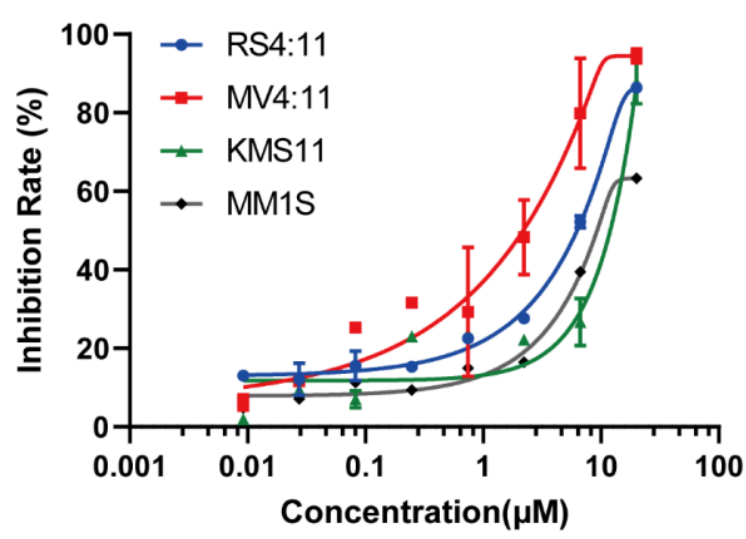

Figure 7. Cellular activities of compound 38. The inhibitory effects on the growth of 4 cell lines treated with $\mathbf{3 8}$ at gradient concentrations for 6 days,. and the inhibitory rate was measured using the CCK8 Kit. Data are reported as the mean $\pm \mathrm{SD}$. 
Next, we further investigated the effects of $\mathbf{3 8}$ on cell cycle progression and apoptosis. The effects of $\mathbf{3 8}$ on cell cycle progression and apoptosis were evaluated in KMS11 and MV4;11 cells. We treated the KMS11 and MV4;11 cells with vehicle alone or 38 at 5 and $10 \mu \mathrm{M}$ for $72 \mathrm{~h}$ and evaluated by flow cytometry ${ }^{[2]}$. A higher proportion of apoptotic cells was observed after the $\mathbf{3 8}$ treatment among the KMS11, and MV4:11 cells and the apoptotic effect is dose-dependent(Fig.8A). Moreover, cell cycle analysis showed that treatment of $\mathbf{3 8}$ in the KMS11, and MV4:11 cells increased the proportions of cells in G0/G1phase whereas decreased the proportions of cells in S and G2/M phase (Fig.8B).

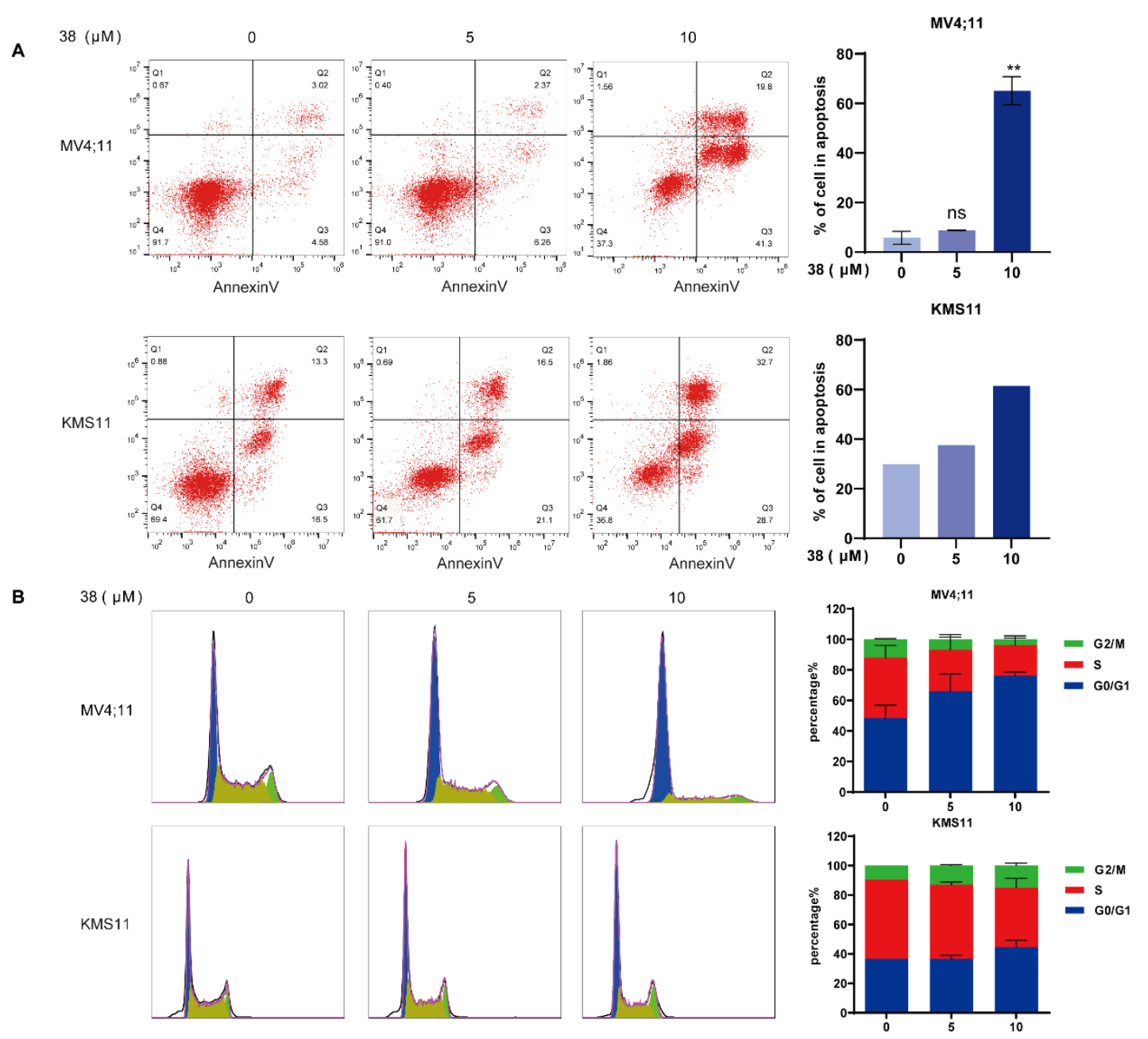

Figure 8. 38 induces cell apoptosis and arrests the cell cycle at the G0/G1 phase in MV4;11 and KMS11 cells. (A) KMS11 and MV4:11 cells were treated with various 
concentrations 38 (at 5 and $10 \mu \mathrm{M}$ ) for $72 \mathrm{~h}$, and the effects on apoptosis were examined by flow cytometry. (B) KMS11 and MV4:11 cells were incubated with $\mathbf{3 8}$ (at 5 and 10 $\mu \mathrm{M})$ for $24 \mathrm{~h}$, and the the percentage of each cell cycle phase were determined by flow cytometry.

\section{CHEMISTRY}

Compounds 5 - 14 and MR837 were prepared as shown in Scheme 1. Beginning with a coupling reaction between $\mathrm{N}$-methylimidazole(48) and 4-bromobenzonitrile(49) or 4-bromo-1-naphthonitrile(58), bromination in the 4-position of N-methylimidazole ring followed. Then, intermediates $\mathbf{6 d - 7 d}, \mathbf{1 3 d - 1 4 d}$ were synthesised via SuzukiMiyaura coupling reaction between $6 \mathbf{b}$ and $6 \mathbf{c}-7 \mathbf{c}, 13 \mathbf{c}-14 \mathbf{c}$, which was obtained from materials 50-51 and 57. Finally, compounds 6-7, 13-14 was afforded after reductive amination. But compounds 8-12 take slightly different routes. Materials 53-56 were transformed into intermediates $\mathbf{9 c - 1 2 c}$ via reduction of the cyanide group, NH-Boc protection, boronation of bromobenzenes. After intermediates $9 c-12 c$ and materials $\mathbf{5 2}$ coupling with intermediate $\mathbf{6 b}$, intermediates 8d-12d was obtained. In the end, compounds 8-12 was afforded via deprotection of NH-Boc protection group. Compound MR837 was synthesized by reductive amination and condensation with materials 59 and 60 as starting point.

Synthetic routes for preparing compounds $\mathbf{1 6 - 1 8}$ is slightly different from that of compounds 8-12 at that the cyanide group could convert to NH-Boc protected benzylamine in one step, showed as in schme 2. 
Preparation of compounds $\mathbf{1 9 - 2 5}$ is indicated as in schme 3. Synthetic routes for preparing compound 19 is similar to that of compounds 8-12. In the synthesis of compound 20-21, the synthesis of 4-(4-bromo-1-methyl-1H-imidazol-5-yl) benzonitrile derivatives $\mathbf{2 0 b}-\mathbf{2 1 b}$ had been improved by a one-step coupling reaction of materials 65 and materials 64 or intermediate $21 \mathrm{a}$, and the rest was similar to the synthesis of compound 8-12. However, in the process of obtaining compound 22-25, 4(4-bromo-1-methyl-1H-imidazol-5-yl) benzonitrile derivatives 22b-25b was obtained via Suzuki- Miyaura coupling reaction and bromination in the 4-position of Nmethylimidazole ring with materials $\mathbf{6 6}$ and the corresponding borate ester or boric acid derivatives 66, 23a, 69 and 25a as starting point. Among them of intermediate 23a and 25a was derived from materials 68 and 70.

As indicated in schme 4, preparation of compounds 19-25 was compeleted via Suzuki- Miyaura coupling reaction, reduction or deprotection of NH-Boc protection group with intermediate 14b and the corresponding borate ester derivatives $\mathbf{2 6 c}, \mathbf{1 3 c}$, 28c and 31c. Among them of intermediates 26c, 28c and 31c, intermediate 26c was derived from material 62, and intermediate 28c was obtained by addition of material $\mathbf{6 2}$ and ethyl magnesium bromide, followed by boronation, intermediate 31c was obtained via introduction of $\mathrm{NH}-\mathrm{Boc}$ protection group, boronation with materials $\mathbf{7 1}$ as starting point.

Besides, the preparation of aliphatic amine derivatives 33-45 of compound 27 and corresponding derivatives $\mathbf{4 6} \mathbf{- 4 7}$ of intermediate $\mathbf{1 3 d}$ is summarized in Scheme 5. 
Compound 27 or intermediate 13d was transformed to the corresponding derivatives via reductive amination and additional deprotection of NH-Boc protection group.

\section{Scheme 1. Synthesis of Compounds $6-14^{\mathrm{a}}$}

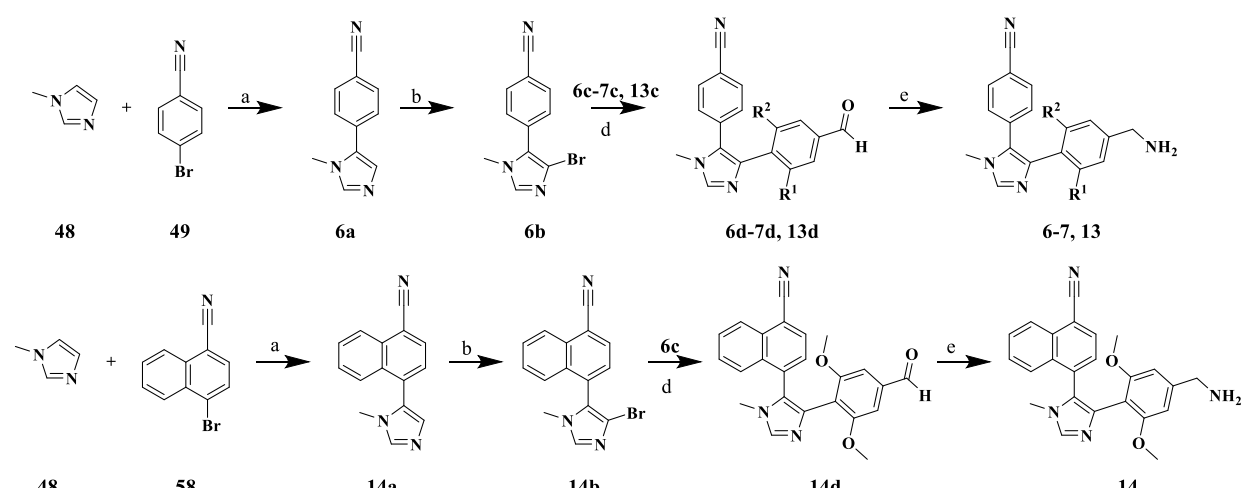

$48 \quad 58$

14a

$14 \mathrm{~b}$

$14 \mathrm{~d}$

14
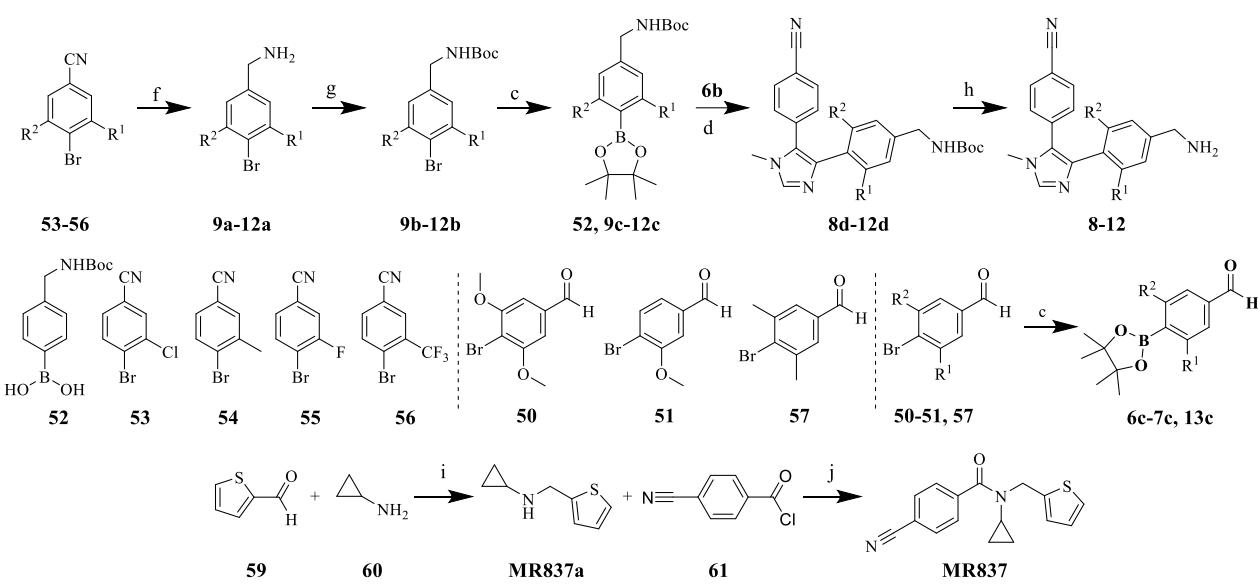

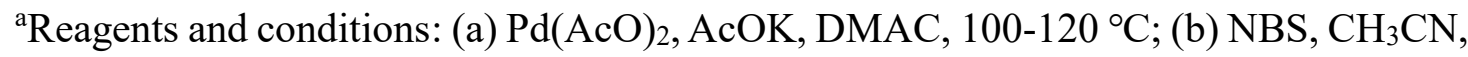
under ice bath; (c) (Bpin) $2, \mathrm{PdCl}_{2}$ (dppf), $\mathrm{AcOK}$, dioxane or DMSO, 60-80 ${ }^{\circ} \mathrm{C}$; (d) $\mathrm{PdCl}_{2}$ (dppf), $\mathrm{K}_{2} \mathrm{CO}_{3}$, dioxane $/ \mathrm{H}_{2} \mathrm{O}, 80-120{ }^{\circ} \mathrm{C}$ or XPhos $\mathrm{Pd} \mathrm{G} 2, \mathrm{~K}_{3} \mathrm{PO}_{4}$, dioxane $/ \mathrm{H}_{2} \mathrm{O}$, $90{ }^{\circ} \mathrm{C}$; (e) $\mathrm{CH}_{3} \mathrm{COONH}_{4}, \mathrm{NaCNBH}_{3}, \mathrm{MeOH}$, under ice bath; (f) $\mathrm{BH}_{3} / \mathrm{THF}$, THF, $0{ }^{\circ} \mathrm{C}$ room temperature, overnight; $\quad(\mathrm{g})(\mathrm{Boc})_{2} \mathrm{O}$, DIPEA, DCM, at room temperature; (h) trifluoroacetic acid, DCM, at room temperature; (i) $\mathrm{NaCNBH}_{3}, \mathrm{MeOH}$, under ice bath; （j） DIPEA, $\mathrm{CH}_{3} \mathrm{CN}$, at room temperature.

\section{Scheme 2. Synthesis of Compounds $15-18^{\mathrm{a}}$}




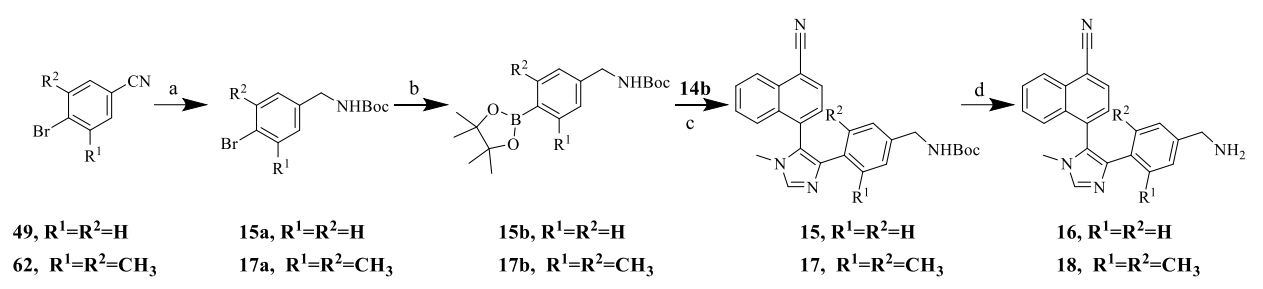

${ }^{a}$ Reagents and conditions: (a) $(\mathrm{Boc})_{2}, \mathrm{NiCl}_{2}\left(\mathrm{H}_{2} \mathrm{O}\right)_{6}, \mathrm{NaBH}_{4}, \mathrm{MeOH}$, under ice bath;

(b) (Bpin) $)_{2}, \mathrm{PdCl}_{2}$ (dppf), $\mathrm{AcOK}$, dioxane or DMSO, 60-80 ${ }^{\circ} \mathrm{C}$; (c) $\mathrm{PdCl}_{2}$ (dppf), $\mathrm{K}_{2} \mathrm{CO}_{3}$, dioxane/ $\mathrm{H}_{2} \mathrm{O}, 80-120{ }^{\circ} \mathrm{C}$; (d) $4 \mathrm{M} \mathrm{HCl}$ dioxane solution, at room temperature.

Scheme 3. Synthesis of Compounds 19-25a

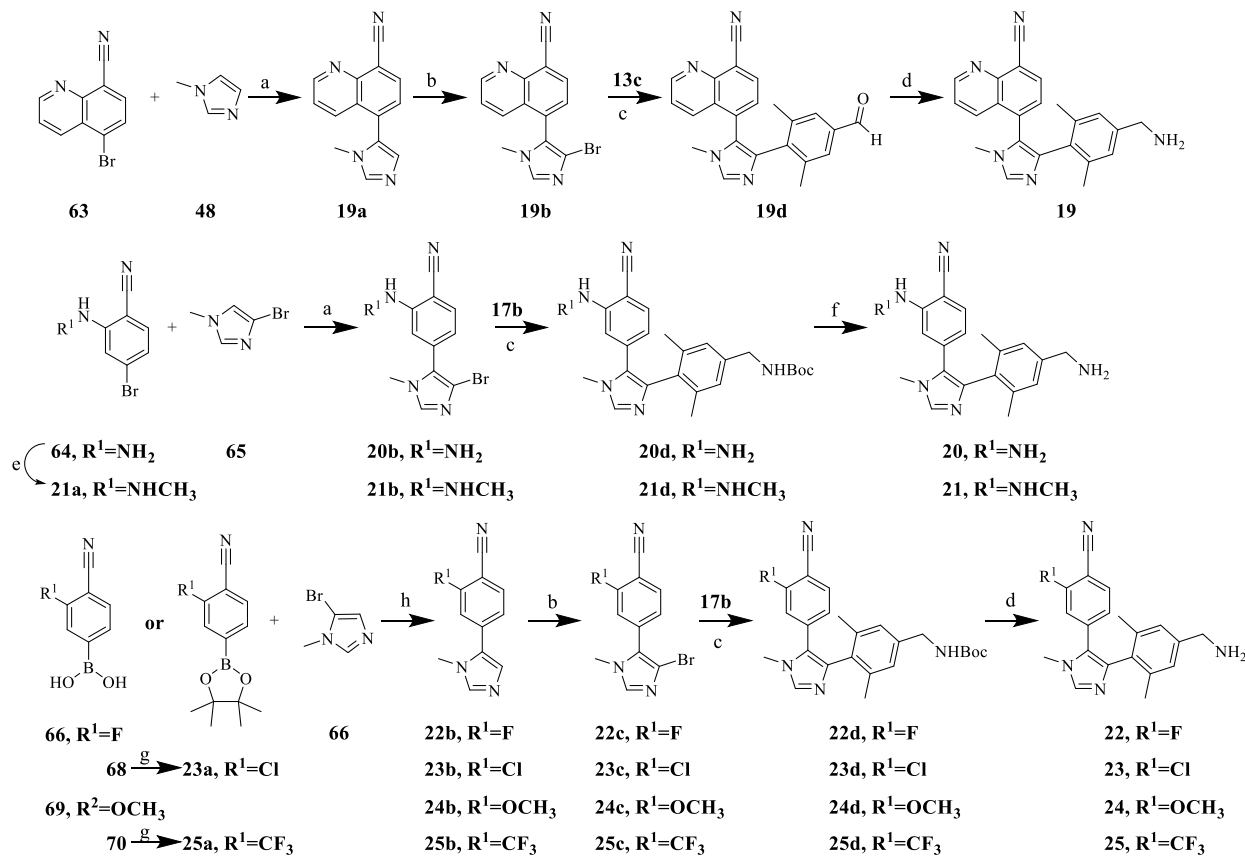

${ }^{a}$ Reagents and conditions: (a) $\mathrm{Pd}(\mathrm{AcO})_{2}$, $\mathrm{AcOK}$, DMAC, $100-120^{\circ} \mathrm{C}$; (b) $\mathrm{NBS}, \mathrm{CH}_{3} \mathrm{CN}$;

(c) $\mathrm{Pd}$ (amphos) $\mathrm{Cl}_{2}, \mathrm{Cs}_{2} \mathrm{CO}_{3}$, dioxane/ $\mathrm{H}_{2} \mathrm{O}, 90-120{ }^{\circ} \mathrm{C}$ or XPhosPdG2, $\mathrm{K}_{3} \mathrm{PO}_{4}$, dioxane/

$\mathrm{H}_{2} \mathrm{O}, 90{ }^{\circ} \mathrm{C}$; （d ） $\mathrm{CH}_{3} \mathrm{COONH}_{4}, \mathrm{NaCNBH}_{3}, \mathrm{MeOH}$, under ice bath; (e) ;(f) $4 \mathrm{M} \mathrm{HCl}$ dioxane solution, at room temperature. (g) (Bpin) $)_{2}, \mathrm{Pd}(\mathrm{OAc})_{2}$, AcOK, DMSO, 60-80 ${ }^{\circ} \mathrm{C}$; (h) $\mathrm{Pd}(\mathrm{dppf}) \mathrm{Cl}_{2}, \mathrm{Na}_{2} \mathrm{CO}_{3}, \mathrm{EtOH}, \mathrm{H}_{2} \mathrm{O}$, toluene, $90{ }^{\circ} \mathrm{C}$.

Scheme 4. Synthesis of Compounds 26-32a 


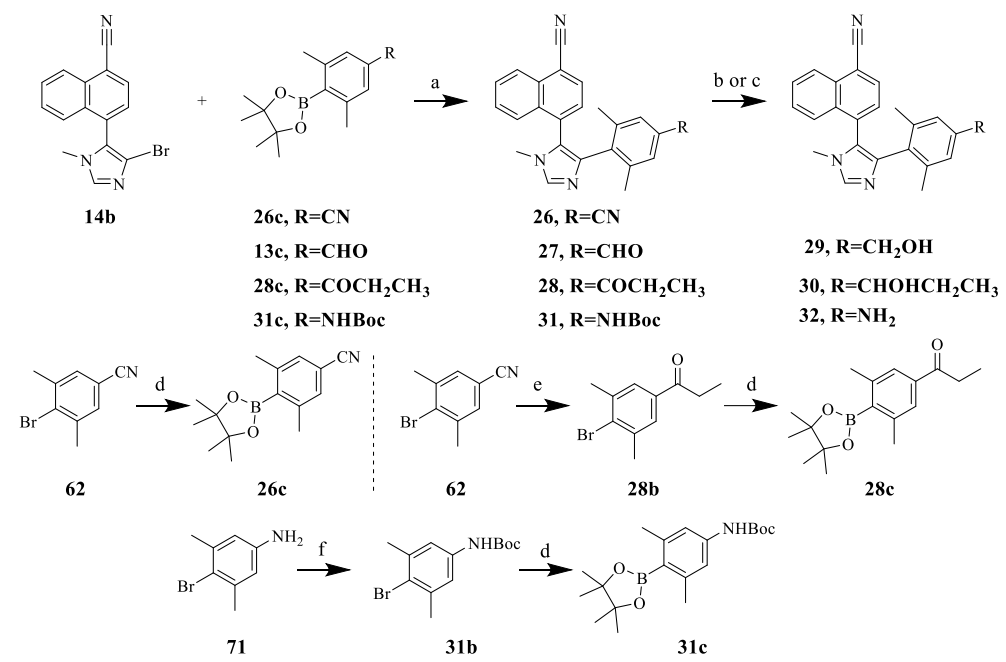

${ }^{\text {a}}$ Reagents and conditions: (a) $\mathrm{Pd}($ amphos $) \mathrm{Cl}_{2}, \mathrm{Cs}_{2} \mathrm{CO}_{3}$, dioxane $/ \mathrm{H}_{2} \mathrm{O}, 90-120{ }^{\circ} \mathrm{C}$ or $\mathrm{PCy}_{3}, \mathrm{~K}_{3} \mathrm{PO}_{4}$, toluene, $110^{\circ} \mathrm{C}$; (b) $\mathrm{NaBH}_{4}, \mathrm{MeOH}$, at room temperature; (c) $4 \mathrm{M} \mathrm{HCl}$ dioxane solution, at room temperature. (d) (Bpin) $)_{2}, \mathrm{PdCl}_{2}(\mathrm{dppf}), \mathrm{AcOK}$, dioxane, 80$100{ }^{\circ} \mathrm{C}$; (e) $\mathrm{CuI}, \mathrm{CH}_{3} \mathrm{CH}_{2} \mathrm{MgBr}$, THF, at room temperature; (f) (Boc)2, EtOH, at room temperature.

Scheme 5. Synthesis of Compounds 33-47

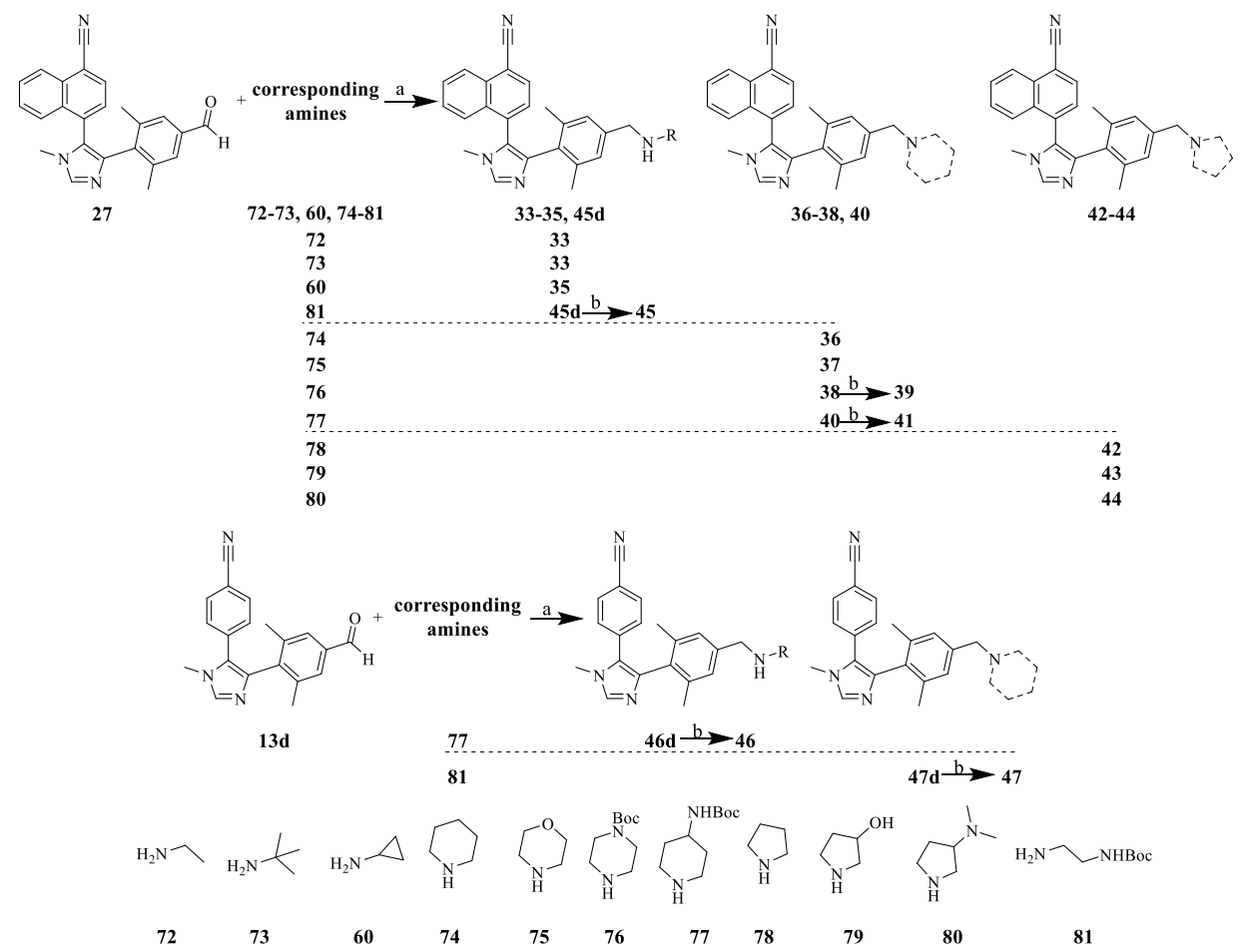


${ }^{\text {a}}$ Reagents and conditions: (a ) $\mathrm{CH}_{3} \mathrm{COONH}_{4}, \mathrm{NaCNBH}_{3}, \mathrm{MeOH}$, under ice bath; (b) 4M HCl dioxane solution, at room temperature.

\section{CONCLUSIONS}

Based on reported NSD3 PWWP1 inhibitor BI-9321 and NSD2 PWWP1 inhibitor MR837, we discovered a selective and in vitro effective NSD2-PWWP1 inhibitor 38 via rationally design and subsequent structure-based optimization. Compound $\mathbf{3 8}$ exhibited good potency against NSD2 PWWP1 $\left(\mathrm{IC}_{50}=0.11 \pm 0.01 \mu \mathrm{M}\right)$ and excellent selectivity over other PWWP domains. Finally, compound $\mathbf{3 8}$ was clarified as the most potent compound, which presented quite good enzyme inhibition activity and single digit micromole level of cell proliferation inhibition activity, after our unremitting efforts on optimizing the structure of the compounds.

\section{EXPERIMENTAL SECTION}

General Chemistry Information. ${ }^{1} \mathrm{H}$ NMR (400 MHz) spectra were recorded by using Varian Mercury-400 high performance digital FT-NMR spectrometer or Bruker Advance $500 \mathrm{MHz} / 600 \mathrm{MHz}$ spectrometer with tetramethylsilane (TMS) as an internal standard. ${ }^{13} \mathrm{C}$ NMR (100 or $125 \mathrm{MHz}$ ) spectra were recorded by using a Varian Mercury-400 high performance digital FT-NMR spectrometer or Varian Mercury 500 $\mathrm{MHz} / 600 \mathrm{MHz}$ high performance digital FTNMR spectrometer. NMR data are reported as follows: chemical shift, integration, multiplicity (s, singlet; d, doublet; t, triplet; $\mathrm{m}$, multiplet; dd, doublet of doublets; brs, broad singlet), and coupling constants. Protons of hydroxyl and amino groups are not always indicated as very broad peaks. Low- 
resolution mass spectra were obtained with Thermo Fisher Finnigan LTQ or Finnigan LCQ Deca XP mass spectrometer using a CAPCELL PAK C18 $(50 \mathrm{~mm} \times 2.0 \mathrm{~mm}, 5$ $\mu \mathrm{m})$ or an Agilent ZORBAX Eclipse XDB C18 $(50 \mathrm{~mm} \times 2.1 \mathrm{~mm}, 5 \mu \mathrm{m})$ in positive or negative electrospray mode. High resolution mass spectra were recorded by using a Finnigan MAT-95 mass spectrometer or an Agilent Technologies G6520 TOF mass spectrometer or Agilent G6230 TOF LC/MS spectrometer. The purity of compounds was determined by high performance liquid chromatography (HPLC) and mostly confirmed to be more than 95\%. Purity of all compounds (except for compounds $\mathbf{4 5}$, 46 and 47) was determined by analytical Gilson-215 high performance liquid chromatography using an YMC ODS3 column $(50 \mathrm{~mm} \times 4.6 \mathrm{~mm}, 5 \mu \mathrm{m})$. Conditions were as follows: $\mathrm{CH}_{3} \mathrm{CN} / \mathrm{H}_{2} \mathrm{O}$ eluent at $2.5 \mathrm{~mL} / \mathrm{min}$ flow [containing $0.1 \%$ trifluoroacetic acid (TFA)] at $35{ }^{\circ} \mathrm{C}, 8 \mathrm{~min}$, gradient $5 \% \mathrm{CH}_{3} \mathrm{CN}$ to $95 \% \mathrm{CH}_{3} \mathrm{CN}$, monitored by UV absorption at 214 and $254 \mathrm{~nm}$. Purity of compounds $\mathbf{4 5 ,} 46$ and 47 were determined by analytical Agilent-1290 high performance liquid chromatography using a Waters BEH C18 column $(50 \mathrm{~mm} \times 2.1 \mathrm{~mm}, 1.7 \mu \mathrm{m})$. Conditions were as follows: $\mathrm{CH}_{3} \mathrm{CN} / \mathrm{H}_{2} \mathrm{O}$ eluent at $0.5 \mathrm{~mL} / \mathrm{min}$ flow [containing $0.1 \%$ trifluoroacetic acid (TFA)] at $40{ }^{\circ} \mathrm{C}, 5 \mathrm{~min}$, gradient $5 \% \mathrm{CH}_{3} \mathrm{CN}$ to $80 \% \mathrm{CH}_{3} \mathrm{CN}$, monitored by $\mathrm{UV}$ absorption at 214 and $254 \mathrm{~nm}$. TLC analysis was carried out with glass precoated silica gel GF254 plates. TLC spots were visualized under UV light. All solvents and reagents were used directly as obtained commercially unless otherwise noted. All air and moisture sensitive reactions were carried out under an atmosphere of dry argon/nitrogen with heat-dried glassware and standard syringe techniques. Column chromatography 
was carried out on silica gel (200-300 mesh). Some final compounds were all purified by $\mathrm{C} 18$ reverse phase preparative Shim-pack GIS column $(5 \mathrm{~mm} \mathrm{C18,} \mathrm{30*250} \mathrm{mm)}$ with solvent $\mathrm{A}\left(0.1 \%\right.$ TFA in $\left.\mathrm{H}_{2} \mathrm{O}\right)$ and solvent $\mathrm{B}\left(0.1 \%\right.$ TFA in $\left.\mathrm{CH}_{3} \mathrm{CN}\right)$ as eluents. Most compounds were eventually converted to hydrochloride $(6-7,13-14,16,18-21$, 26-30, 32, 33-37, 39, 41-47) or trifluoroacetate (8-12, 22-25), except for compound MR837 and compounds 15, 17, 31, 18 and 40 that protected by NH-Boc group.

Biological Assay Methods. Protein Expression and Purification. DNA fragment encoding amino acids 211 to 350 of NSD2-PWWP1 subcloned in the pET-28 plasmid was produced by Shanghai Generay Biotech Co. Ltd. The constructed plasmid containing six histidine or sumo tags in the N-terminus was transformed into Escherichia coli BL21(DE3) cell with heat shock. Transformed E. coli cells were grown to an OD600 of $1.2-1.5$ at $37{ }^{\circ} \mathrm{C}$ in TB medium containing $50 \mathrm{mg} / \mathrm{L}$ kanamycin. Then, the culture temperature was reduced to $18{ }^{\circ} \mathrm{C}$ and the cultures were then induced with $0.5 \mathrm{mM}$ IPTG for $16 \mathrm{~h}$. The bacterial cells were harvested after centrifugation, washed with PBS for 3 times and frozen at $-80{ }^{\circ} \mathrm{C}$. Harvested bacterial cells were lysed with ultra-high pressure cell disrupter (UH-03, Union, Shanghai, China) in lysis buffer (50 $\mathrm{mM}$ Tris, $\mathrm{pH} 8.0,50 \mathrm{mM} \mathrm{NaCl}, 5 \%$ glycerol, and $0.5 \mathrm{mM}$ TCEP). The supernatant was collected after centrifugation at $12000 \mathrm{rpm}$ for $60 \mathrm{~min}$. Subsequently, Ni Sepherose was added to the supernatant to bind to the protein, and the target protein was eluted with a buffer containing $250 \mathrm{mM}$ imidazole. The target protein was concentrated and purified with exclusion chromatography (Superdex 200 10/300 GL124mL) which was balanced by buffer (50 mM HEPES, $50 \mathrm{mM} \mathrm{NaCl}, 5 \%$ glycerol, $\mathrm{pH} 8.0$ and $0.5 \mathrm{mM}$ TCEP). 
Purified NSD2-PWWP1 protein concentrated to $10 \mathrm{mg} / \mathrm{ml}$ with approximately $95 \%$ purity was either used to set up crystals or flash frozen in liquid nitrogen for storage at $-78^{\circ} \mathrm{C}$.

Crystallization and X-ray Crystallography The vapor diffusion method was used for crystallization of aliquots of the purified proteins. The protein of NSD2PWWP1, and the ligands were grown at $16^{\circ} \mathrm{C}$ in $1 \mu \mathrm{L}$ of protein with an equal volume of reservoir solution containing the $1.6 \mathrm{M}$ ammonium sulfate, $0.01 \mathrm{M}$ magnesium chloride, 0.1 M HEPES at pH 7.5. Crystals grew to diffracting quality within 1 week. Data was collected at $100 \mathrm{~K}$ on beam line BL17U at the Shanghai Synchrotron Radiation Facility (SSRF) (Shanghai, China) for the co-crystallized structures. ${ }^{15}$ The data were processed with the XDS software packages ${ }^{16}$, and the structures were then solved by molecular replacement using the PHENIX software package. ${ }^{17}$ The search model used for the crystals was the NSD2-PWWP1 complex structure (PDB code 6UE6). The structures were refined using the CCP4 program REFMAC5 ${ }^{18}$ combined with the simulated annealing protocol implemented in the program PHENIX. With the aid of the program $\operatorname{Coot}^{19}$, compound, water molecules, and others were fitted into the initial $F_{\mathrm{o}}-F_{\mathrm{c}}$ maps.

Enzymatic Assays for NSD2-PWWP1. The enzyme activity was determined by HTRF assay which was conducted according to the manufacturer's protocol (Cisbio) in a 96-well plate. First, $5 \mu \mathrm{L}$ of 4 nM NSD2 PWWP1 diluent buffer and $5 \mu \mathrm{L}$ of the substrate substrate polypeptide diluent buffer was added to each well, then $5 \mu \mathrm{L}$ of the 
corresponding concentration of compounds dissolved in diluent buffer, finally, $5 \mu \mathrm{L}$ of $\mathrm{Tb} / \mathrm{d} 2$ mixture were then added. After incubated at room temperature for $3 \mathrm{~h}$, the plate was read on a microplate reader (BioTek Cytation 5) at 665 and $620 \mathrm{~nm}$. HTRF signals were calculated as a ratio as follows: (intensity of $665 \mathrm{~nm}) /($ intensity of $620 \mathrm{~nm}) \times 10^{4}$. All compounds were dissolved in DMSO and added to the medium at a final 1:1000 dilution. All experiments were repeated at least twice. The enzyme activity calculation formula was as follows: Inhibition= (maximum intensity for complete binding of protein and peptide- intensity after adding the inhibitor $) /($ maximum intensity for complete binding of protein and peptide- background values of intensity only containing $\mathrm{Tb}$ and $\mathrm{d} 2) \times 100 \%$. The calculation of compounds $\mathrm{IC}_{50}$ took the logarithm of compound concentration as the abscissa, and the corresponding inhibition ratio as the ordinate, and nonlinear fitting was performed. The reagents and equipment used in this experiment were as follows: the fluorescent donor was Anti-His $\mathrm{Tb}$ (Cisbio,PerkinElmer), the fluorescent receptor was Streptavidin-d2, the protein was His-NSD2-PWWP1(211-350aa) purified in our laboratory, and the substrate polypeptide was Biotin-ATKAARKSAPATGGV-Lys (me)2-KPHRYRPG (Shanghai Desheng Pharmaceutical Technology Co., Ltd), buffer used from Cisbio Perkinelmer. Thermal shift assay Melting curves of proteins with and without the presence of compounds were determined by TSA using the Protein thermal shift ${ }^{\mathrm{TM}}$ Dye Kit (Life Technologies). The kit containing Protein Thermal Shift ${ }^{\mathrm{TM}}$ Buffer and Protein Thermal Shift ${ }^{\mathrm{TM}}$ Dye. The reaction system contained 5ul Protein Thermal Shift ${ }^{\mathrm{TM}}$ Buffer, 2.5ul Diluted Protein Thermal Shift ${ }^{\mathrm{TM}}$ Dye $(8 X)$ and $12.5 \mathrm{ul}$ Water + protein + buffer and/or 
buffer components. The melting curve was generated by heating the plate with a slope of $2.5 \mathrm{oC} / \mathrm{min}$ from $25^{\circ} \mathrm{C}$ to $95^{\circ} \mathrm{C}$. The assay was performed on QuantStudioTM 6 Flex real-time PCR machine (Applied Biosystems) and analyzed by the software Protein

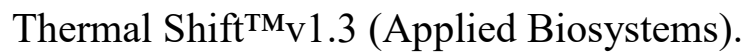

AlphaLISA NSD2 Histone H3 Lysine-N-methyltransferase assay AlphaLISA NSD2 Histone H3 Lysine-N-methyltransferase assay were used to determined the $\mathrm{IC}_{50}$ of compound 9c. The enzyme prep was diluted in assay buffer before use. SAM (TAKA) was used as the methyl group donor and unmethylated histone H3 (Anaspec) was used as a substrate. All these components were incubated at room temperature (r.t.) for 20 min. Add $5 \mu \mathrm{L}$ of high salt buffer to stop the NSD2 enzymatic reaction. Cover the plate with TopSeal-A film and incubate $30 \mathrm{~min}$ at room temperature (r.t.) acceptor beads, biotinylatedanti-H3 antibody and donor beads were then diluted in $1 \mathrm{X}$ detection buffer (PerkinElmer) before use. Acceptor beads/biotinylated antibody mix were then added at a final concentration of $20 \mu \mathrm{g} / \mathrm{mL}$ and $1 \mathrm{nM}$ to the reaction mixture and the plate was incubated at r.t. for $1 \mathrm{~h}$. Donor beads were added at a final concentration of $20 \mu \mathrm{g} / \mathrm{mL}$ and the plate was incubated at r.t. for $30 \mathrm{~min}$ in subdued light. The reaction was run in 384-well plates. The plates were read using an EnVision ${ }^{\circledR}$ reader. The resultant data were analyzed with graphPad prism.

Western Blot analysis Total cellular extracts were lysed in buffer containing 2\% SDS and quantified by the method of BCA protein assay. An equal amount of protein was subjected to electrophoresis on SDS-PAGE and transferred to nitrocellulose membranes, incubated with primary antibodies and then incubated with secondary antibody at room temperature for $1 \mathrm{~h}$. Primary antibodies used were as follows: antibeta-actin(Proteintech Group, 66009-1-lg), anti-histone H3 (Cell Signaling Technology, \#9715), anti-WHSC1/NSD2(abcam, ab75359), anti-Di-Methyl-Histone H3 (Lys36) 
(Cell Signaling Technology, \#2901). The detection was performed using a SuperSignal west pico stable peroxide solution (Thermo Fisher Scientific).

Cell proliferation assay The cell lines used in each experiment were obtained from the American Type Culture Collection. The cell line RS4:11, and KMS11 were cultured in the altered RPMI-1640 medium (Invitrogen) supplemented with 10\% FBS (Gibco) and $2 \mathrm{mM}$ lglutamine. The MV4:11 cell line was maintained in IMDM (Iscove's Modified Dulbecco's Medium) supplemented with 10\% selected FBS (Gibco). For the cell proliferation assay, Cells were plated in 96-well plates at 6000-20000 cells per well in a volume of $200 \mu \mathrm{L}$ for $24 \mathrm{~h}$. Then different concentrations of diluted compounds or DMSO added into the the cells and were cultured for another $6 \mathrm{~d}$. Dosages corresponding to the half maximal inhibition (IC50) were detected using the cell counting kit-8 (Life Technologies) according to the manufacturer's instructions.

Cell cycle analysis and annexin V staining Cell cycle analysis was conducted by incorporating propidium iodide (PI). The cells were treated with $10 \mathrm{uM}, 5 \mathrm{uM} 033$ or DMSO control for $48 \mathrm{~h}$. Then cells were harvested and resuspended in PBS and fixed by $70 \%$ pre-cooled ethanol overnight. Then Cells were washed with PBS and resuspended in stain buffer containing $5 \mu \mathrm{g} / \mathrm{mL}$ ribonuclease A (Sigma-Aldrich) and 5 $\mu \mathrm{g} / \mathrm{mL}$ PI for $45 \mathrm{~min}$ in room tempreture for $40 \mathrm{~min}$. Acquisition was immediately performed on FACSCanto (BD Biosciences), and results were analyzed using modifit software.

Annexin V binding assay was used for apoptosis assay. The cells were cultured in 6 well plates at the optimal density. After 24h, different concentrations of the test compounds or DMSO control was added in the plates for another $72 \mathrm{~h}$. Then, $10^{5}$ cells were collected and re-suspended in $100 \mu \mathrm{L}$ annexin $\mathrm{V}$ binding solution containing $0.25 \mu \mathrm{g} / \mathrm{mL}$ anti-annexin $\mathrm{V}$-FITC and $1 \mu \mathrm{g} / \mathrm{mL}$ 
PI in the dark for $10 \mathrm{~min}$. Samples were diluted with $400 \mu \mathrm{L}$ annexin V binding solution and analyzed by flow cytometry.

RNA extraction and Real -time PCR Total RNA was extracted with the EZ-press RNA Purification Kit (B0004DP) on the basis of manufacturer's prospectus. Reverse transcription was performed in a $20 \mu \mathrm{L}$ reaction volume with the total $2 \mu \mathrm{g}$ of RNA using HiScript II Q RT SuperMix (\#R222-01, Vazyme, Nanjing, China). Real -time PCR were performed with SYBR Green Master Mix (\#Q121-02, Vazyme) according to the manufacture's recommended protocol.

The following sequences of primers were designed to amplify PCR product:

GAPDH:

5'-GAGTCCACTGGCGTCTTCAC-3'

5'-TTCACACCCATGACGAACAT-3'

PAK1:

5'-GGTTTCAAGTGTTTAGTAACTTTTCCA-3'

5'-TTAGCTGCAGCAATCAGTGG-3'

RRAS2:

5'-GAGCAGCCCGGCTAGATATT-3'

5'-TGTTCTCTCATGGCTCCAAA-3'

TGFA:

5'-CCTGGCTGTCCTTATCATCAC-3'

5'-GGCACCACTCACAGTGTTTTC-3'

TEMEL2:

5'-CCACAGGGTTGCGTCTCAG-3'

5'-GGAGCACTGCACAGACAGAG-3'

HSPG2: 
5'-CCAAATGCGCTGGACACATTC-3'

5'-CGGACACCTCTCGGAACTCT-3'

NCAM1:

5'-GGCATTTACAAGTGTGTGGTTAC-3'

5'-TTGGCGCATTCTTGAACATGA-3'

\section{ACKNOWLEDGMENTS}

We are grateful for financial support from the National Natural Science Foundation of China (Grant 21922707 and 81773572), the Major projects of National Natural Science Foundation of China (Grant 81991523), the Collaborative Innovation Cluster Project of Shanghai Municipal Commission of Health and Family Planning (Grant 2019CXJQ02), the Natural Science Foundation of Shanghai (21ZR1475500). Open Program of State Key Laboratory of new Drug development (Grant SIMM2105KF-04), SA-SIBS Scholarship Program and Shanghai Municipal Science and Technology Major Project. This work was carried out with the support of Shanghai Synchrotron Radiation Facility. We also thank Prof. Huan Zhou for the assistance in determination of co-crystal structure.

\section{References}

1. Vougiouklakis, T.; Hamamoto, R.; Nakamura, Y.; Saloura, V. The NSD family of protein methyltransferases in human cancer. Epigenomics 2015, 7, 863-74.

2. Bennett, R. L.; Swaroop, A.; Troche, C.; Licht, J. D. The Role of Nuclear Receptor-Binding SET Domain Family Histone Lysine Methyltransferases in Cancer. Cold Spring Harb Perspect Med 2017, 7 . 
3. Cheong, C. M.; Mrozik, K. M.; Hewett, D. R.; Bell, E.; Panagopoulos, V.; Noll, J. E.; Licht, J. D.; Gronthos, S.; Zannettino, A. C. W.; Vandyke, K. Twist-1 is upregulated by NSD2 and contributes to tumour dissemination and an epithelial-mesenchymal transition-like gene expression signature in t(4;14)-positive multiple myeloma. Cancer Lett 2020, 475, 99-108.

4. Pierro, J.; Saliba, J.; Narang, S.; Sethia, G.; Saint Fleur-Lominy, S.; Chowdhury, A.; Qualls, A.; Fay, H.; Kilberg, H. L.; Moriyama, T.; Fuller, T. J.; Teachey, D. T.; Schmiegelow, K.; Yang, J. J.; Loh, M. L.; Brown, P. A.; Zhang, J.; Ma, X.; Tsirigos, A.; Evensen, N. A.; Carroll, W. L. The NSD2 p.E1099K Mutation Is Enriched at Relapse and Confers Drug Resistance in a Cell ContextDependent Manner in Pediatric Acute Lymphoblastic Leukemia. Mol Cancer Res 2020, 18, 1153 1165.

5. Chen, R.; Chen, Y.; Zhao, W.; Fang, C.; Zhou, W.; Yang, X.; Ji, M. The Role of Methyltransferase NSD2 as a Potential Oncogene in Human Solid Tumors. Onco Targets Ther 2020, $13,6837-6846$.

6. Sengupta, D.; Zeng, L.; Li, Y.; Hausmann, S.; Ghosh, D.; Yuan, G.; Nguyen, T. N.; Lyu, R.; Caporicci, M.; Morales Benitez, A.; Coles, G. L.; Kharchenko, V.; Czaban, I.; Azhibek, D.; Fischle, W.; Jaremko, M.; Wistuba, II; Sage, J.; Jaremko, L.; Li, W.; Mazur, P. K.; Gozani, O. NSD2 dimethylation at $\mathrm{H} 3 \mathrm{~K} 36$ promotes lung adenocarcinoma pathogenesis. Mol Cell 2021.

7. Weinberg, D. N.; Papillon-Cavanagh, S.; Chen, H.; Yue, Y.; Chen, X.; Rajagopalan, K. N.; Horth, C.; McGuire, J. T.; Xu, X.; Nikbakht, H.; Lemiesz, A. E.; Marchione, D. M.; Marunde, M. R.; Meiners, M. J.; Cheek, M. A.; Keogh, M. C.; Bareke, E.; Djedid, A.; Harutyunyan, A. S.; Jabado, N.; Garcia, B. A.; Li, H.; Allis, C. D.; Majewski, J.; Lu, C. The histone mark H3K36me2 recruits DNMT3A and shapes the intergenic DNA methylation landscape. Nature 2019, 573, 281-286. 
8. Yuan, S.; Natesan, R.; Sanchez-Rivera, F. J.; Li, J.; Bhanu, N. V.; Yamazoe, T.; Lin, J. H.; Merrell, A. J.; Sela, Y.; Thomas, S. K.; Jiang, Y.; Plesset, J. B.; Miller, E. M.; Shi, J.; Garcia, B. A.; Lowe, S. W.; Asangani, I. A.; Stanger, B. Z. Global Regulation of the Histone Mark H3K36me2 Underlies Epithelial Plasticity and Metastatic Progression. Cancer Discov 2020, 10, 854-871.

9. Huang, H.; Howard, C. A.; Zari, S.; Cho, H. J.; Shukla, S.; Li, H.; Ndoj, J.; Gonzalez-Alonso, P.; Nikolaidis, C.; Abbott, J.; Rogawski, D. S.; Potopnyk, M. A.; Kempinska, K.; Miao, H.; Purohit, T.; Henderson, A.; Mapp, A.; Sulis, M. L.; Ferrando, A.; Grembecka, J.; Cierpicki, T. Covalent inhibition of NSD1 histone methyltransferase. Nat Chem Biol 2020, 16, 1403-1410.

10. Bottcher, J.; Dilworth, D.; Reiser, U.; Neumuller, R. A.; Schleicher, M.; Petronczki, M.; Zeeb, M.; Mischerikow, N.; Allali-Hassani, A.; Szewczyk, M. M.; Li, F.; Kennedy, S.; Vedadi, M.; Barsyte-Lovejoy, D.; Brown, P. J.; Huber, K. V. M.; Rogers, C. M.; Wells, C. I.; Fedorov, O.; Rumpel, K.; Zoephel, A.; Mayer, M.; Wunberg, T.; Bose, D.; Zahn, S.; Arnhof, H.; Berger, H.; Reiser, C.; Hormann, A.; Krammer, T.; Corcokovic, M.; Sharps, B.; Winkler, S.; Haring, D.; Cockcroft, X. L.; Fuchs, J. E.; Mullauer, B.; Weiss-Puxbaum, A.; Gerstberger, T.; Boehmelt, G.; Vakoc, C. R.; Arrowsmith, C. H.; Pearson, M.; McConnell, D. B. Fragment-based discovery of a chemical probe for the PWWP1 domain of NSD3. Nat Chem Biol 2019, 15, 822-829.

11. Coussens, N. P.; Kales, S. C.; Henderson, M. J.; Lee, O. W.; Horiuchi, K. Y.; Wang, Y.; Chen, Q.; Kuznetsova, E.; Wu, J.; Chakka, S.; Cheff, D. M.; Cheng, K. C.; Shinn, P.; Brimacombe, K. R.; Shen, M.; Simeonov, A.; Lal-Nag, M.; Ma, H.; Jadhav, A.; Hall, M. D. High-throughput screening with nucleosome substrate identifies small-molecule inhibitors of the human histone lysine methyltransferase NSD2. J Biol Chem 2018, 293, 13750-13765.

12. Ferreira de Freitas, R.; Liu, Y.; Szewczyk, M. M.; Mehta, N.; Li, F.; McLeod, D.; Zepeda- 
Velazquez, C.; Dilworth, D.; Hanley, R. P.; Gibson, E.; Brown, P. J.; Al-Awar, R.; James, L. I.; Arrowsmith, C. H.; Barsyte-Lovejoy, D.; Min, J.; Vedadi, M.; Schapira, M.; Allali-Hassani, A. Discovery of Small-Molecule Antagonists of the PWWP Domain of NSD2. J Med Chem 2021, 64, $1584-1592$.

13. Sankaran, S. M.; Wilkinson, A. W.; Elias, J. E.; Gozani, O. A PWWP Domain of HistoneLysine N-Methyltransferase NSD2 Binds to Dimethylated Lys-36 of Histone H3 and Regulates NSD2 Function at Chromatin. J Biol Chem 2016, 291, 8465-74.

14. Wang, S.; Yang, H.; Su, M.; Lian, F.; Cong, Z.; Wei, R.; Zhou, Y.; Li, X.; Zheng, X.; Li, C.; Fu, X.; Han, X.; Shi, Q.; Li, C.; Zhang, N.; Geng, M.; Liu, H.; Li, J.; Huang, X.; Wang, J. 5Aminonaphthalene derivatives as selective nonnucleoside nuclear receptor binding SET domainprotein 2 (NSD2) inhibitors for the treatment of multiple myeloma. Eur J Med Chem 2021, 222, 113592.

15. Wang, Q.; Yu, F.; Cui, Y.; Zhang, K.; Pan, Q.; Zhong, C.; Liu, K.; Zhou, H.; Sun, B.; He, J. Mini-beam modes on standard MX beamline BL17U at SSRF. Rev Sci Instrum 2017, 88, 073301.

16. Kabsch, W. Processing of X-ray snapshots from crystals in random orientations. Acta Crystallogr D Biol Crystallogr 2014, 70, 2204-16.

17. Adams, P. D.; Afonine, P. V.; Bunkoczi, G.; Chen, V. B.; Echols, N.; Headd, J. J.; Hung, L. W.; Jain, S.; Kapral, G. J.; Grosse Kunstleve, R. W.; McCoy, A. J.; Moriarty, N. W.; Oeffner, R. D.; Read, R. J.; Richardson, D. C.; Richardson, J. S.; Terwilliger, T. C.; Zwart, P. H. The Phenix software for automated determination of macromolecular structures. Methods 2011, 55, 94-106.

18. Kovalevskiy, O.; Nicholls, R. A.; Long, F.; Carlon, A.; Murshudov, G. N. Overview of refinement procedures within REFMAC5: utilizing data from different sources. Acta Crystallogr D 
Struct Biol 2018, 74, 215-227.

19. Emsley, P.; Lohkamp, B.; Scott, W. G.; Cowtan, K. Features and development of Coot. Acta Crystallogr D Biol Crystallogr 2010, 66, 486-501. 